\title{
Cleanrooms and tissue banking how happy I could be with either GMP or GTP?
}

\author{
J. Klykens · J.-P. Pirnay • G. Verbeken • \\ O. Giet $\cdot$ E. Baudoux $\cdot$ R. Jashari ·
}

A. Vanderkelen $\cdot$ N. Ectors

Received: 28 April 2011 / Accepted: 17 December 2012

(C) Springer Science+Business Media Dordrecht 2013

\begin{abstract}
The regulatory framework of tissue banking introduces a number of requirements for monitoring cleanrooms for processing tissue or cell grafts. Although a number of requirements were clearly defined, some requirements are open for interpretation. This study aims to contribute to the interpretation of GMP or GTP guidelines for tissue banking. Based on the experience of the participating centers, the results of the monitoring program were evaluated to determine the feasibility of a cleanroom in tissue banking and the monitoring program. Also the microbial efficacy of a laminar airflow cabinet and an incubator in a cleanroom environment was evaluated. This study indicated that a monitoring program of a cleanroom at rest in combination with (final) product testing is a feasible approach. Although no statistical significance $(0.90<p<0.95)$ was found there is a strong indication that a Grade D environment is
\end{abstract}

J. Klykens $(\varangle) \cdot$ N. Ectors

Cell and Tissue Banks, University Hospitals Leuven, UZ

Gasthuisberg, Herestraat, 49, 3000 Leuven, Belgium

e-mail: johan.klykens@uzleuven.be

J.-P. Pirnay · G. Verbeken · A. Vanderkelen

Cell and Tissue Banks, Queen Astrid Military Hospital,

Brussels, Belgium

O. Giet · E. Baudoux

Cell and Tissue Banks, University Hospital Liège, Liège,

Belgium

R. Jashari · A. Vanderkelen

European Homograft Bank, Brussels, Belgium not the ideal background environment for a Grade A obtained through a laminar airflow cabinet. The microbial contamination of an incubator in a cleanroom is limited but requires closed containers for tissue and cell products.

Keywords Clean room - Tissue banking - Laminar airflow cabinet - Incubator - GMP · GTP · Microbial · Particle $\cdot$ Monitoring $\cdot$ Controlled environment

\section{Introduction}

Regulatory framework

The Directive 2004/23/EC of the European Parliament and of the Council of 31 March 2004 on setting standards of quality and safety for the donation, procurement, testing, processing, preservation, storage and distribution of human tissues and cells has been supplemented by a number of other directives. As for example the Commission directive 2006/86/EC of 24 October 2006 that was written to implement Directive 2004/23/EC of the European Parliament and of the Council as regards traceability requirements, notification of serious adverse reactions and events and certain technical requirements for the coding, processing, preservation, storage and distribution of human tissues and cells.

In particular the technical requirements for processing human tissues and cells were of some concern to 
numerous cell and tissue banks. It was stated that the air quality standard during the processing of tissues and cells is a key factor that may influence the risk of tissue or cell contamination. Moreover, an air quality with particle counts and microbial colony counts equivalent to those of Grade A, as defined in the European Guide to Good Manufacturing Practice, Annex 1 and Commission Directive 2003/94/EC, is considered to be generally required. Finally, the background environment appropriate for the processing of the tissue/cell concerned is at least equivalent to GMP Grade D in terms of particles and microbial counts. Hereby establishing a definite link between cell and tissue banking and GMP.

GMP was successfully developed as an iterative continuous improvement process in an effort to improve quality of pharmaceutical products, as described by Slopecki et al. (2007) It started off as a guideline with specific tasks, but evolved to guidelines based on quality management principles. Annex 1 of the GMP relates to the manufacture of sterile medicinal products. The basic principle being "manufacture of sterile products is subject to special requirements in order to minimize risks of microbiological contamination, and of particulate and pyrogen contamination." However, annex 1 does not lay down detailed methods for determining the microbiological and particulate cleanliness of air, surfaces etc. stating only: "Reference should be made to other documents such as the EN/ISO Standards." The principles of GMP will have to be applied with a fair dose of common sense and the knowledge of the particularities of tissue banks. The European directives on tissue banking target the safety and availability of grafts for clinical use. Correct translation and interpretation is crucial to reach the goals outlined in the European guidelines as demonstrated by Langstrom and Hartvig (2007). On the other hand, theoretical approaches to implementing GMP can easily lead to excessive and unwarranted restrictions.

In 2005 the food and drug administration (FDA) required human cell, tissue, and cellular and tissuebased product (HCT/P) establishments to follow current good tissue practice (CGTP), which governs the methods used in, and the facilities and controls used for, the manufacture of HCT/Ps; recordkeeping; and the establishment of a quality program. The CGTP regulations supplement the current good manufacturing practice (CGMP) and quality system (QS) regulations. GTP's could be an interpretation dedicated to tissue banking. European Good Tissue Practices are currently being developed within the setting of a European Union Project in the framework of the Public Health Program. Unfortunately, up til now there is not a lot of detail in GTP, whether they are European in draft or US, about the specific interpretation for controlled environments dedicated to tissue banking.

The different European directives have been transposed into the Belgian law of the 19th of December 2008 on the procurement and use of human tissues for medical applications and scientific research. Different royal decrees clarify specific issues and aspects such the appropriate environment. In keeping with the Commission directive 2006/86/EC the environment should conform to GMP Grade A in a background of GMP Grade D except for cells (in open systems), heart, blood vessels and musculo-skeletal grafts where a background Grade $\mathrm{C}$ is required. The limits for microbial contamination in the different GMP Grade environments are resumed in Table 1.

\section{Controlled environments}

Holbrook (2010) and Briggs Phillips (1965) described the history of controlled environments. 1850s watchmakers were the first to implement techniques to prevent dirt in their factory (Holbrook 2010) and in 1885, workers interested in germ-free life developed many types of mechanical barrier or isolation systems (Briggs Phillips 1965). In 1915 the first controlled environment was documented (Kuster 1915). It describes an area, with entrance air locks and air filters, that operates under positive pressure for the breading of germ-free goats. In 1950 the medical field discovered controlled environments as a protective measure against antibiotic resistant staphylococcus. In our current world, controlled environments are applied in several industries. Pharmaceutical industry, operating theatres in hospitals, production of micro-electronics, space industry all use controlled environments to protect against contamination.

A cleanroom (Fr. salle blanche) is an environment, typically used in production or research, that has a low level of environmental contaminants such as dust, airborne microbes, aerosol particles and chemical vapors etc. More accurately, a cleanroom has a controlled level of contamination that is specified by the number of particles per cubic meter of a specified particle size. Thus, a cleanroom is a fairly extreme 
Table 1 Recommended limits for microbiological contamination (GMP Annex A)

a These are average values

b Individual settle plates may be exposed for less than $4 \mathrm{~h}$

\begin{tabular}{lllll}
\hline Grade & \multicolumn{4}{l}{ Recommended limits for microbial contamination ${ }^{\mathrm{a}}$} \\
\cline { 2 - 5 } & $\begin{array}{l}\text { Air sample } \\
\left(\mathrm{CFU} / \mathrm{m}^{3}\right)\end{array}$ & $\begin{array}{l}\text { Settle plates } \\
(\text { diameter } 90 \mathrm{~mm}) \\
(\mathrm{CFU} / 4 \mathrm{~h})^{\mathrm{b}}\end{array}$ & $\begin{array}{l}\text { Contact plates } \\
(\text { diameter 55 mm) } \\
(\text { CFU/plate })\end{array}$ & $\begin{array}{l}\text { Glove print } \\
5 \text { fingers } \\
(\text { CFU/glove })\end{array}$ \\
\hline $\mathrm{A}$ & $<1$ & $<1$ & $<1$ & $<1$ \\
$\mathrm{~B}$ & 10 & 5 & 5 & 5 \\
$\mathrm{C}$ & 100 & 50 & 25 & - \\
$\mathrm{D}$ & 200 & 100 & 50 & - \\
\hline
\end{tabular}

form of controlled environment. The European directive compels the use of a controlled environment for the processing of human tissues and cells. However, the degree of variability in human tissues and cells as well as processes is important. Moreover, different classes of controlled environments can/should be used. Finally, the basic material to be processed in a controlled environment is frequently non-sterile (e.g. skin).

Taking these considerations into account the authors decided on a multicenter study focusing on the monitoring of controlled environments in human tissue and cell banking and aiming at generating a contribution to either the interpretation of GMP guidelines for tissue banking or the translation to GTP guidelines.

\section{Project}

\section{Participants}

17 human tissue and cell banks from four centers were included. Table 2 shows the types of tissues and cells processed by these banks as well as the classification of the respective controlled processing environments.

\section{Monitoring of controlled environments (EN ISO 14698-1:2003 based)}

Inventory of the monitoring techniques:

- Settle plates: $90 \mathrm{~mm}$ petri dishes containing Trypticase Soy Agar (TSA), are left open for 4 h. Petri dishes are closed and incubated for $48 \mathrm{~h}$ at $37{ }^{\circ} \mathrm{C}$. Some tissue banks also include testing with a
Sabouraud agar plate incubated for 5-10 days at $30{ }^{\circ} \mathrm{C}$ ( $4 / 4$ centers).

- Contact plate: different contact plates are used

- $90 \mathrm{~mm}$ Rodac plates are pressed against a surface. The contact plates are closed and incubated for $48 \mathrm{~h}$ at $37^{\circ} \mathrm{C}$ (3/4 centers).

- $55 \mathrm{~mm}$ TSA plates used in combination with $55 \mathrm{~mm}$ Sabouraud agar plates. Plates are pressed onto the surface and closed. TSA plates are incubated for $72 \mathrm{~h}$ at $30{ }^{\circ} \mathrm{C}$, followed by $48 \mathrm{~h}$ at $20{ }^{\circ} \mathrm{C}$. Sabouraud agar plates are incubated for $120 \mathrm{~h}$ at $25^{\circ} \mathrm{C}$ or 5-10 days at $30{ }^{\circ} \mathrm{C}(1 / 4$ centers $)$.

- Air sampling: $90 \mathrm{~mm}$ TSA plates are used in combination with a device for air sampling (MAS100 or Air Ideal). Samples of 5001 or 10001 are taken. Plates are closed and incubated for $48 \mathrm{~h}$ at $37{ }^{\circ} \mathrm{C}$ ( $4 / 4$ centers).

- Glove prints: the thumb is pressed directly on the surface of a $55 \mathrm{~mm}$ TSA plate. Plates are incubated for $48 \mathrm{~h}$ at $37{ }^{\circ} \mathrm{C}$ ( $3 / 4$ centers).

- Swabs are inoculated onto TSA plates and incubated for $48 \mathrm{~h}$ at $37{ }^{\circ} \mathrm{C}$ (2/4 centers).

All monitoring methods are described in the United States Pharmacopeia 29 (2005). We used these descriptions because there is debate as to the proper interpretation of the GMP guidelines (Schicht 2006).

Inventory of the the monitoring data

EN ISO 14698 - 1:2003 (cleanrooms and associated controlled environments-biocontamination control) advises to install an environmental monitoring program (including type, location and frequency of sampling) based on a risk assessment procedure such 
Table 2 Overview of the processed tissues and cells and the Grades of the controlled processing environments

\begin{tabular}{|c|c|c|c|}
\hline & $\begin{array}{l}\text { Grade } \\
\mathrm{A} \text { in } \mathrm{B}\end{array}$ & $\begin{array}{l}\text { Grade } \\
\mathrm{A} \text { in } \mathrm{C}\end{array}$ & $\begin{array}{l}\text { Grade } \\
A \text { in D }\end{array}$ \\
\hline Hematopoietic stem cells & & 1 & 2 \\
\hline Musculo-skeletal tissues & 1 & & \\
\hline Tympano-ossicular grafts & 1 & & \\
\hline Keratinocytes & 1 & 1 & \\
\hline Placental membranes & 1 & & \\
\hline Cord blood & & 1 & 1 \\
\hline Cellular therapy: dendritic cells & & 1 & \\
\hline $\begin{array}{l}\text { Cellular therapy: mesenchymal } \\
\text { cells }\end{array}$ & & 1 & \\
\hline Ophthalmic tissues & 1 & & \\
\hline Heart valves & 1 & & \\
\hline Blood vessels & 1 & & \\
\hline Skin & 1 & 1 & \\
\hline
\end{tabular}

Time frame: data were collected over a 2 year period (20092010)

as a failure mode, effects and criticality analysis (FMECA), a hazard analysis and critical control points (HACCP) or a quantitative microbiological risk assessment (QMRA). Based on their experience and a risk analysis, the involved tissue and cell banks introduced a standard environmental monitoring program. These monitoring programs resulted in the a number of measurements in an at rest state (Table 3).

Methods for analysis of the monitoring data

Although environmental monitoring is required by all relevant guidelines, methods for data interpretation are not provided by these guidelines. Moreover, the interpretation of microbial contamination data is not straightforward. For example, the EU GMP guidelines define the accepted levels of contamination as average maximum values. The averaging method is not defined (Wilson 2001). Therefore all centers use these average values as the maximum permitted value for each individual measurement.

To compare the different Grades of controlled environments with a low microbial count, all centers collected relevant monitoring data. By calculating the average number of measurements that give a microbial count (larger or equal to $1 \mathrm{CFU}$ ) we are able to compare the different environments using statistical
Table 3 Inventory of the monitoring data (numbers of samples); data was obtained from $4 / 4$ centers

\begin{tabular}{llrl}
\hline & $\begin{array}{l}\text { Air } \\
\text { samples }\end{array}$ & $\begin{array}{l}\text { Settle } \\
\text { plates }\end{array}$ & $\begin{array}{l}\text { Contact } \\
\text { plates }\end{array}$ \\
\hline Laminar air flow cabinet (LAF) & 220 & 141 & 447 \\
Grade B & 36 & 18 & 663 \\
Grade C & 46 & 12 & 24 \\
Grade D & 83 & 9 & 312 \\
\hline
\end{tabular}

As only limited data on glove prints and swabs was available, these results were not included in this study

models based on a normal distribution. This is one of the approaches described in the 'Fundamentals of environmental monitoring' (PDA 2001).

Influence of limited activity and equipment

The standard test program was supplemented with small-scale specific tests. These tests were executed to create background knowledge for further risk assessment:

- Influence of personnel movement in an air lock of a Grade B environment (1/4 centers):

During a measurement of an air sample in an air lock, a standard entering procedure was executed. Results were measured according to the standard procedure. The result was compared to standard monitoring where measurements were done in an at rest state. To reach an at rest state, the person stays in the air lock without movement and the measurement starts 2 min after entrance.

- Influence of non functional laminar air flow cabinets on microbiological contamination during processing ( $1 / 4$ centers):

Four laminar airflow cabinets were left non functional for more than 2 days in a Grade $\mathrm{C}$ environment before measuring the contamination by settle plates. Measurements were done according to the monitoring procedure. Afterwards the LAF's were switched on, cleaned and measured again by settle plates.

- Microbiological contamination of an incubator in a Grade $\mathrm{C}$ background ( $2 / 4$ centers):

We studied the influence of the background contamination on microbiological performance of an incubator. 
Incubators are a hazard for microbiological contamination by means of their elevated temperature $\left(37^{\circ} \mathrm{C}\right)$, elevated humidity and lack of air flow. Seven air samples and 22 contact plates were evaluated in standard procedures as part of the standard monitoring procedure to evaluate whether the standard cleaning and maintenance procedure would be able to limit these risks.

\section{Results}

Monitoring of controlled environments

(EN ISO 14698-1:2003 based)

Monitoring results of air samples, settle plates and contact plates are shown in Table 4 . The percentage of samples with a microbial count (larger or equal to $1 \mathrm{CFU}$ ) and maximum contamination are indicated.

As a general the microbiological contamination can be controlled in the controlled environments of the tissue banks. Measured values remain within the specifications of a controlled environment at rest.

Nine "out of specification" situations occurred in 1911 measurements. Most of these out of "spec" situations were measurements of $2 \mathrm{CFU} / \mathrm{m}^{3}$ in $\mathrm{LAF}$ air samples or impermissible values in contact plates from the floor. All out of "spec" situations were followed by cleaning and re-evaluation. Final product testing during processing showed no contamination of the processed tissue and cell grafts.

Influence of limited activity and equipment

- Influence of personnel movement in an airlock of a Grade B environment (see Table 5).

Entering an air lock increased the level of microbiological contamination. Measurements at rest show distinctly lower results.

- Operational laminar airflow cabinet in a Grade C environment (see Table 6).

The test was performed with 4 laminar airflow cabinets in a Grade $\mathrm{C}$ environment.

- Microbiological contamination of an incubator in a Grade $\mathrm{C}$ environment (see Table 7).

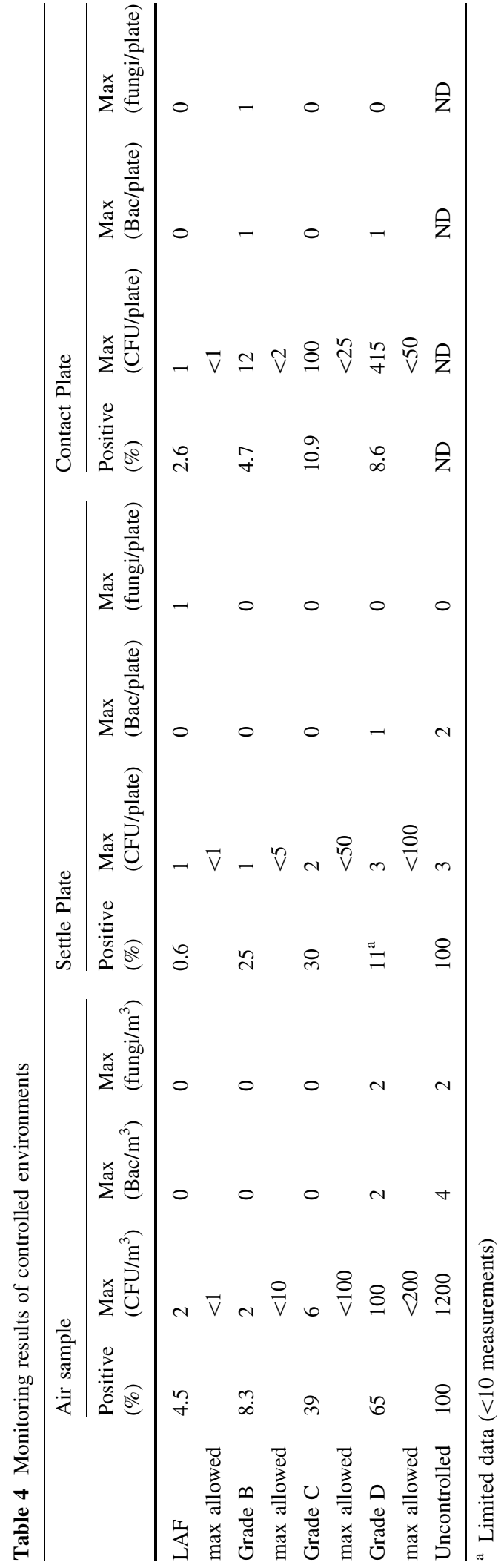


Table 5 Results for personnel movement in an airlock of a Grade B environment

\begin{tabular}{lcll}
\hline & $\mathrm{CFU} / \mathrm{m}^{3}$ & $\mathrm{Bac} / \mathrm{m}^{3}$ & Fungi $/ \mathrm{m}^{3}$ \\
\hline Entering air lock & 60 & 0 & 0 \\
At rest & 4 & 0 & 0 \\
\hline
\end{tabular}

Table 6 Results comparing settle plates in non-operational and operational mode

\begin{tabular}{lllll}
\hline & $\begin{array}{l}\text { Settle } \\
\text { plates }\end{array}$ & $\begin{array}{l}\text { Max } \\
\text { CFU/ } \\
\text { plate }\end{array}$ & $\begin{array}{l}\text { Max } \\
\text { Bac/ } \\
\text { plate }\end{array}$ & $\begin{array}{l}\text { Max } \\
\text { fungi/ } \\
\text { plate }\end{array}$ \\
\hline $\begin{array}{l}\text { Non-operational LAF cabinet } \\
\text { Operational LAF cabinet }\end{array}$ & $3 / 4$ & 2 & 0 & 0 \\
\hline $\begin{array}{l}\text { Non-operational laminar airflow cabinets are } \\
\text { specification. When they were switched on and cleaned, they } \\
\text { returned to (and remained) within specifications }\end{array}$
\end{tabular}

\section{Discussion}

We decided to only compare measurements in an at rest state. In process measurements were considered to be incomparable. Although the involved tissue and cell banks procure donor tissues and cells according to dedicated procedures to limit microbiological contamination during procurement, some donor material will inevitably carry microbial agents after prelevation (e.g. the skin commensal flora). Subsequent processing of these tissues and cells is performed in either closed or open systems and specific procedures are in place to protect personnel and to prevent crosscontamination. The risk associated with in process interventions was also taken into consideration (Cobo et al. 2006).

Although GMP guidelines differ between the US and the EU, the used measurement methods do comply with these guidelines as described by Caselli-Fernandez and Terkola (2006).
Tissue and cell banks operate in controlled environments to reduce the risk of contaminating the allografts. Measurements of settle plates and contact plates show comparable maximum contamination levels as shown in Table 4. This indicates that the contamination measured on the surfaces is largely dependent on the viable contamination of the air. Chances of airborne viable contamination settling down on the allografts are thus related the Grade of the processing environment. Similar findings were described by Whitfield (1966) and Pasquarella et al. (2000). A more recent study shows that the contamination rate of syringes is lower when they are prepared in a controlled environment as compared to a non-controlled environment (Stucki et al. 2009). Similar results were found when monitoring an assisted reproductive technology facility (Herlong et al. 2008) and a peripheral blood progenitor cell (PBPC) products facility (Ritter et al. 2003).

Our results are also congruent with the Nelson and Greenwald (1973) study in which contamination of wound cultures were reduced from 22 to $5 \%$ by moving from a standard operating theatre to a unidirectional airflow. This, again, indicates that, in controlled environments, there is a strong relationship between airborne contamination and surface contamination (wound contamination in this case).

When laminar airflow cabinets were not operational, 3 out of 4 settle plates exhibited a maximum count of 2 CFU. Once the laminar airflow cabinets were back in operation, no positive settle plates were measured. Similar results were reported by Whitfield (1966). An average of 8.8 colonies per settle plate were measured when blowers of unidirectional flow were switched off. The background measurement resulted in an average of 12 colonies per settle plate. When the blowers were switched on, an average lower than $0.1 \mathrm{CFU} /$ plate were measured. When switched off laminar airflow cabinets will obtain microbiological levels comparable to the background contamination.

Table 7 Results of air samples and contact plates measured in an incubator in a Grade C environment

\begin{tabular}{|c|c|c|c|c|c|c|c|c|}
\hline & \multicolumn{4}{|c|}{ Air sample } & \multicolumn{4}{|c|}{ Contact plate } \\
\hline & $\begin{array}{l}\text { Positive } \\
(\%)\end{array}$ & $\begin{array}{l}\mathrm{Max} \\
\mathrm{CFU} / \mathrm{m}^{3}\end{array}$ & $\begin{array}{l}\operatorname{Max} \\
\mathrm{Bac} / \mathrm{m}^{3}\end{array}$ & $\begin{array}{l}\text { Max } \\
\text { fungi/m } 3\end{array}$ & $\begin{array}{l}\text { Positive } \\
(\%)\end{array}$ & $\begin{array}{l}\text { Max } \\
\text { CFU/plate }\end{array}$ & $\begin{array}{l}\text { Max } \\
\text { Bac/plate }\end{array}$ & $\begin{array}{l}\text { Max } \\
\text { fungi/plate }\end{array}$ \\
\hline Incubator in Grade $\mathrm{C}$ background & 14 & 2 & 0 & 0 & 20 & 2 & 0 & 0 \\
\hline
\end{tabular}

Air samples and contact plates show a limited microbiological load. The number of positive tests is comparable 
Table 8 Rate of surface contamination in LAF cabinets in relation to the rate of air contamination of the background environment

\begin{tabular}{lll}
\hline & $\begin{array}{l}\text { Rate of positive } \\
\text { background } \\
\text { air samples }(\%)\end{array}$ & $\begin{array}{l}\text { Rate of positive LAF } \\
\text { contact plates (maximum } \\
\text { CFU measured })(\%)\end{array}$ \\
\hline Grade B & 8.3 & $1.8(<1 \mathrm{CFU} /$ plate $)$ \\
Grade D & 65 & $5.6(<2 \mathrm{CFU} /$ plate $)$
\end{tabular}

Laminar Air flow cabinets are not always put in a Grade B background. Although GMP describes Grade $\mathrm{B}$ as their 'natural environment' we also evaluated the performance of laminar air flow cabinets that were installed in a Grade D background. The WHO describes a Grade A in Grade C and a Grade A in Grade D environment in the draft document concerning the environmental monitoring of cleanrooms in vaccine manufacturing facilities (WHO 2011). Today, similar circumstances are used in tissue and cell banking. We compared the surface contamination of the laminar air flow cabinets that were placed in a Grade B environment with those that were placed in a Grade D background. The contact plate data of the laminar airflow cabinets (Tables 1,2) was re-analyzed taking into account the background environment of the laminar airflow cabinets. The contact plate values are compared to the air sample values of the background environment. The results are shown in Table 8. It is clear that there is an increased rate of surface contamination (contact plates) in a lower (Grade D) background environment.

The analysis suggests that the background environment has an impact on the contamination of surfaces in LAF cabinets, although no statistical significant difference was found $(0.90<p<0.95)$ using either a Chi square test or a Fisher exact test. A background of GMP Grade B seems to reduce the rate of surface contamination in laminar airflow cabinets as compared to a GMP Grade D background. Although the levels of contamination remained low in both background environments, a GMP Grade D environment seemed less consistent in guaranteeing the required surface contamination level for a laminar airflow cabinet. In a draft document (WHO 2011), the WHO proposes to use the standard for settle plates in a Grade B for a laminar airflow cabinet in Grade C or D environment. Since our project was carried out in at rest situation, the results are able to give an indication on the quantification of the impact of the background environment on a microbial efficiency of a laminar airflow cabinet.

We studied the influence of background contamination on the microbiological performance of an incubator. Incubators are a hazard for microbiological contamination by their elevated temperature, elevated humidity and lack of air flow. Our results showed, however, a limited microbiological contamination, comparable to that of the Grade $\mathrm{C}$ background environment (based on limited data).

The incubator background environment must be evaluated keeping in mind that some materials from the incubator will end up on the working surface of the laminar airflow cabinet for open processing. Based on these data we conclude that closed containers (or e.g. culture flasks with a filter cap) seem to be necessary for incubators in a Grade C or D environment. Incubator standard operating procedures, including a standard cleaning schedule and maintenance program, seem to be sufficient to control microbiological contamination in the incubators. We also observed that the different technical constructions of incubators may also influence the protection towards microbiological contamination. We used $\mathrm{CO}_{2}$-incubators with HEPA-filters, without a copper inner construction. Water baths are regularly changed and filled with sterile water.

The impact of entering a controlled environment on the microbiological contamination level was significant. Entering a GMP Grade B airlock caused the maximum level of air contamination to rise from 4 to $60 \mathrm{CFU} / \mathrm{m}^{3}$ at rest. This result is similar to that of a standard particle recovery test.

This test indicates that recovery towards microbiological contamination in the air of a controlled environment is comparable to the recovery of particle contamination.

Similar results were seen when evaluating the contamination of airborne fungal spores between a cleanroom at rest and in operation (Buttner and Stetzenbach 1993). The impact of activity on microbiological contamination 
showed similar results for industrial cleanrooms (Favero et al. 1966).

\section{Conclusions}

A controlled environment is mandatory for tissue and cell processing. A monitoring program based on at rest measurements is feasible for all cell and tissue banks and it is a strong element in the control of the environment in which safe allografts have to be processed.

A GMP Grade D environment does not seem to be an ideal background for a Grade A environment obtained through a laminar air flow cabinet. Further measurements are required to evaluate the efficacy of a GMP Grade $\mathrm{C}$ environment as a background for a Grade A laminar airflow cabinet. The contamination in an incubator is determined by the background contamination of the controlled environment in which the incubator is installed. The contamination level is limited in standard operations, although closed containers seem to be necessary to protect products where background environments don't qualify for open processing.

\section{References}

Briggs Phillips G (1965) Technical manuscript 260: microbiological barrier techniques. US Army Biological laboratories, Fort Detrick

Buttner MP, Stetzenbach LD (1993) Monitoring airborne fungal spores in an experimental indoor environment to evaluate sampling methods and the effects of human activity on air sampling. Appl Environ Microbiol 59:219-226

Caselli-Fernandez LM, Terkola R (2006) Clean room environment, personnel, quality assurance and their monitoring. Eur J Hosp Pharm Pract 12:29-34

Cobo F, Stacey G, Cortes JL, Concha A (2006) Environmental monitoring in stem cell banks. Appl Microbiol Biotechnol 70:651-662

European Commission (2006) Directive 2006/86/EG implementing Directive 2004/23/EC of the European parliament and of the council as regards traceability requirements, notification of serious adverse reactions and events and certain technical requirements for the coding, processing, preservation, storage and distribution of human tissues and cells

European Commission (2008) vol. 4 EU Guidelines to Good Manufacturing Practice Medicinal Products for Human and
Veterinary Use-Annex 1 Manufacture of Sterile Medicinal Products

European Union (2004) Directive 2004/23/CE of the European parliament and the council of March 31st relating to the establishment of quality and safety norms to donate, to obtain, to assess, to process, to preserve, to store and to distribute human cells and human tissues

Favero MS, Puleo JR, Marshall JH (1966) Comparative levels and types of microbiological contamination detected in industrial cleanrooms. Appl Microbiol 14(4):540-551

Herlong JL, Reubish K, Highdon HL III, Boone WR (2008) Quantitative and qualitative analysis of microorganisms in an assisted reproductive technology facility. Fertil Steril 89(4):847-853

Holbrook D (2010) Controlling contamination: the origins of cleanroom technology. Hist Technol 25(3):173-191

ISO 14698:2003 Cleanrooms and associated controlled environments-Biocontamination control

Kuster E (1915) Die gewinnung, halting und aufzuche keimfreier tiere and ihre bedeutiung fur die erforschung naturlicher lebersvorgange. Arb Kaierl Gesundh 48:1-79

Langstrom B, Hartvig P (2007) GMP, three letters with many interpretations. Eur J Nucl Med Mol Imaging 35(4):693-694

Nelson CL, Greenwald AS (1973) Clean air and total hip arthroplasty. Clevel Clin Q 39(3):101-107

Pasquarella C, Pitzurra O, Savino A (2000) The index of microbial air contamination. J Hosp Infect 46:241-256

PDA (2001) Fundamentals of an environmental monitoring program. Technical report no. 13. J Pharm Sci Technol 55(5):1-35

Ritter M, Schwedler J, Beyer J, Movassaghi K, Mutters R, Neubauer A, Schwella N (2003) Bacterial contamination of ex vivo processed PBPC products under cleanroom conditions. Transfusion 43:1587-1595

Schicht H (2006) Regulatory guidance for manufacturing sterile pharmaceutical products-recent EC and FDA developments, bioprocess and biopartnering. Touchbriefings, London, pp 42-44

Slopecki A, Smith K, Moore S (2007) The value of good manufacturing practice to a blood service in managing the delivery of quality. Vox Sang 92:187-196

Stucki C, Sautter AM, Favet J, Bonnabry P (2009) Microbiological contamination of syringes during preparation: the direct influence of environmental cleanliness and risk manipulations on end-product quality. Am J Health Syst Pharm 66:2032-2036

United States Pharmacopeia 29 (2005) < 1116> Microbiological evaluation of cleanrooms and other controlled environments. USP29-NF24 p2969

Whitfield WJ (1966) Microbiological studies of laminar flow rooms. From annual convention of the parenteral drug association, New York. UNCL. Orig. Report no SC-DC-66-2277

WHO (2011) Environmental monitoring of cleanrooms in vaccine manufacturing facilities. Eight Draft, 27 February 2011

Wilson J (2001) Environmental Monitoring: misconceptions and misapplications. J Pharm Sci Technol 55(3):185-190 